\title{
Novos odres para o sagrado vinho: Marià Corbí e os sem religião
}

\author{
Clóvis Ecco* \\ José Reinaldo Felipe Martins Filho**
}

\section{Resumo}

Valendo-se de um diálogo com o pensamento do catalão Marià Corbí, o artigo que segue procura elucidar quais são as principais características da religião na contemporaneidade e, de modo especial, como compreender o fenômeno crescente de espiritualidades que se autointitulam "não religiosas" - como é o caso dos "crentes sem religião", por exemplo. Para isso, demonstra a ambiguidade latente ao redor do termo "religião" e de como este era compreendido pelas sociedades ditas "pré-industriais", nas quais vigorava uma leitura estanque do mundo, em que a religião era tomada como sinônimo de monopólio cultural, versus as sociedades dinâmicas - e/ou fluidas - do período "industrial", cujo principal objetivo é a emancipação do indivíduo de quaisquer amarras que antes o mantinham sob sujeição. Considerando essa distinção, a religião do presente deveria ser considerada "não religiosa", uma vez que se destina à configuração de um novo paradigma. Daí que o próprio uso da expressão "religião" mereça ser substituído por outras palavras como "espiritualidade", "religiosidade", entre outras, na tentativa de amenizar o peso da dimensão institucional antes evocada. Em suma, o fim das religiões, antevisto por muitos como o natural resultado do processo empreendido pelas sociedades em secularização, parece ter sido frustrado pelo advento das novas "espiritualidades" não religiosas. Estas que, por sua vez, permanecem como um constante desafio para a Teologia e as Ciências da Religião.

Palavras-chave: Espiritualidades não religiosas. Marià Corbí. Secularização. Crentes sem religião.

* Doutor em Ciências Sociais e da Religião pela PUC Goiás. Professor Titular e Coordenador no Programa de Pós-graduação Stricto Sensu em Ciências da Religião da PUC Goiás. Autor de artigos e livros pertinentes à área. E-mail: clovisecco@uol.com.br

** Doutorando em Ciências da Religião pela PUC Goiás, sob orientação do prof. Dr. Clóvis Ecco. Mestre em Filosofia (2014) e em Música (2016), ambos pela UFG. Especialista em Sociologia da Religião. Professor de Filosofia no Instituto de Filosofia e Teologia de Goiás (IFITEG) e na PUC Goiás. E-mail: jreinaldomartins@gmail.com 


\title{
New cups for sacred wine: Marià Corbí and the believers without religion
}

\begin{abstract}
Using a dialogue with the catalan Marià Corbí's thought, the following article seeks to elucidate the main characteristics of religion in contemporary times and, in a special way, to understand the growing phenomenon of "non-religious" self-denominating spiritualties - as is the case of "non-religion believers", for example. To do so, it demonstrates the latent ambiguity surrounding the term "religion" and how it was understood by so-called "preindustrial" societies, in which there was a static reading of the world, where religion was taken as synonymous with cultural monopoly, versus the dynamic and/or fluid-societies of the "industrial" period, whose primary purpose is the emancipation of the individual from any ties that once held him under subjection. Considering this distinction, the religion of the present should be considered "non-religious", since it is intended to configure a new paradigm. Hence the very use of the expression "religion" deserves to be replaced by other words such as "spirituality", "religiosity", among others, in an attempt to soften the weight of the institutional dimension previously mentioned. In short, the end of religions, foreseen by many as the natural result of the process undertaken by societies in secularization, seems to have been thwarted by the advent of new non-religious "spiritualties". These, in turn, remain a constant challenge for Theology and the Sciences of Religion.
\end{abstract}

Key-words: Non-religious spiritualities. Marià Corbi. Secularization. Believers without religion.

\section{Nuevas copas para el sagrado vino: Mariá Corbí y los sin religión}

\section{Resumen}

Al valerse de un diálogo con el pensamiento del catalán Marià Corbí, el artículo que sigue procura dilucidar cuáles son las principales características de la religión en la contemporaneidad y, de modo especial, cómo comprender el fenómeno creciente de espiritualidades que se auto intitulan "no religiosas" - como es el caso de los "creyentes sin religión”, por ejemplo. Para ello, demuestra la ambigüedad latente alrededor del término "religión" y de cómo éste era comprendido por las sociedades denominadas "preindustriales", en las que vigía una lectura estanca del mundo, en que la religión era tomada como sinónimo de monopolio cultural, versus a las sociedades dinámicas y/o fluidas - del período "industrial”, cuyo principal objetivo es la emancipación del individuo de cualesquiera amarras que antes lo mantenían bajo sujeción. En vista de esta distinción, la religión del presente debería considerarse "no religiosa", ya que está destinada a la configuración de un nuevo paradigma. De ahí que el propio uso de la expresión "religión" merezca ser sustituido en otras palabras como "espiritualidad", "religiosidad", entre otras, en el intento de amenizar el peso de la dimensión institucional antes evocada. En suma, el fin de las religiones, anticipado por muchos como el natural resultado del proceso emprendido por las sociedades en secularización, parece haber sido frustrado por el advenimiento de las nuevas "espiritualidades" no religiosas. Las 
que, a su vez, permanecen como un constante desafío para la Teología y las Ciencias de la Religión.

Palabras clave: Espiritualidad no religiosa. Marià Corbí. Secularización. Creyentes sin religión.

Eu não sei que grande distância medeia entre o ponto de vista do homem do povo que, observando um terremoto, uma inundação, ou a passagem de um cometa, conclui logo que o mundo vai acabar, e o ponto de vista de certos filósofos que, diante da incredulidade e indiferença religiosa dos nossos dias induzem como lei o fim da religião (TOBIAS BARRETO, 1904).

\section{Desencantamento, secularização, crise de plausibilidade}

Pensar a religião na atualidade requer deparar-se não apenas com um contexto de crises, em sua maioria oriundas da redefinição dos valores e padrões sociais operada desde a modernidade, mas, muito além disso, considerar os novos esboços que se afirmam como respostas a fenômenos como a secularização, o desencantamento do mundo e a crise de plausibilidade aos quais as instituições religiosas, antes tidas como hegemônicas, vêm paulatinamente sendo submetidas. Se, por um lado, é verdade que a modernidade deixou como herança a emancipação do ser humano e sua desvinculação da égide de uma concepção de mundo que o colocava em segundo plano - posto em detrimento em prol da imagem de um Deus creator omnium - por outro também é preciso reconhecer que os resultados de tal autonomia não foram apenas positivos. Isso porque a crise das instituições estendeu-se ao universo da economia, da cultura e da história, obrigando-nos a (re)construir novas bases sobre as quais estabelecemos a nossa visão de mundo. Nesse sentido, entre os pilares francamente assolados pelo processo de dicotomização da realidade, insistentemente submetida à cisão entre o material e o espiritual, certamente esteve a religião. Deslancharam previsões de que após o advento do "homem moderno" a religião não mais encontraria espaço, seja na dinâmica social, seja no estabelecimento de sentido individual - o que pode ser notado a partir do bem humorado fragmento do brasileiro Tobias Barreto, ao abordar o tema ainda nos primeiros anos do século XX, conforme a epígrafe já mencionada.

Valendo-se do termo alemão Entrauberung (que tem como núcleo Zauber), Max Weber (2004) sugere que as sociedades do futuro marcariam sua distância de qualquer espécie de simbolismo referente aos âmbitos da magia, do encanto ou da fascinação. O Entzauberung der Welt chama a atenção para o que poderíamos traduzir como uma "desmagificação" do mundo, à seme- 
lhança do que o poeta Friedrich Von Schiller havia destacado ao sentenciar o Entgötterung der Natur, isto é, o "desendeusamento" da natureza. Desse modo, nem à natureza, nem à dimensão do sagrado caberia o domínio do homem novo, fruto do esclarecimento. Por conseguinte, disposto na esteira do pensamento weberiano o que tradicionalmente nomeamos como o "desencantamento do mundo" traz consigo o conteúdo do que, mais recentemente, Peter Berger apresentaria como a "perda de sentido" (cf. PIERUCCI, 2003, p. 30).

É verdade que o tema da crise de sentido parece adquirir significativa importância em $O$ dossel sagrado, transparecendo, por exemplo, na identificação do que Berger (1985) considera como uma das principais contribuições da religião para as sociedades humanas, qual seja, a imposição de nomia. Fato é que a contemporaneidade não mais corresponde ao modelo legado pelos séculos que nos precederam, especialmente caso pensemos a respeito da fluidez nas relações, o que nos força a reconhecer, inclusive, novas formas de conceber a identidade - formas maleáveis e menos estagnadas que a maioria das concepções de outrora. ${ }^{1}$ Assim, também a função da religião como reguladora da ordem social precisou ser repensada - especialmente em face dos reiterados processos de secularização espalhados mundo afora. Isto posto, se para Berger (1985, p. 119) "por secularização devemos entender o processo pelo qual setores da sociedade e da cultura são subtraídos à dominação das instituições e símbolos religiosos", por sua vez, é igualmente verdadeiro que tal processo não alcançou com igual impacto as diferentes sociedades modernas - entre as quais vale a pena expressar nossa deferência ao contexto latino-americano (para não dizer brasileiro) das últimas décadas.

Conforme observou Jean-Pierre Bastian (1997), em se tratando da América Latina o investimento da modernidade custou a chegar. Como se não bastasse, mesmo após ter se instaurado entre nós, também não se assemelhou ao ocorrido em regiões como a Europa, por exemplo, especialmente no que tange à propagação do ateísmo como resposta à crise de sentido e à falta de plausibilidade das instituições religiosas. Em terras latino-americanas, a marca da modernização parece ter sido, ao contrário, distribuída em dois movimentos distintos: em um primeiro momento, coadunando-se ao que

\footnotetext{
Danilo Martuccelli fala a esse respeito demonstrando quão ultrapassada se tornou a antiga concepção de identidade cunhada pela modernidade. A época contemporânea, com traços predominantes do multiculturalismo, exige a formatação de novas concepções. Tomando por base a insurgência dos fenômenos da globalização, das democracias e das imigrações, o autor introduz o conceito de etnicidade, como substituto para a concepção essencialista de identidade (cf. MARTUCCELLI, 2006).
} 
Bastian (1997) denominou como "mobilidade religiosa" -, os fiéis que, com base em seus próprios interesses, rebelaram-se contra a instituição religiosa à qual pertenciam, aderindo a outras formas institucionais da religião; contudo, e agora pensando a realidade mais atual, à disseminação do que tem sido encarado como a categoria dos "crentes sem religião", ${ }^{2}$ isto é, pessoas que embora absolutamente desacreditadas das instituições, mantêm-se profundamente cônscias de suas crenças (crendo em um Deus, em uma força, na vida pós-morte etc...) a um ponto de forjarem novas maneiras de se expressarem religiosamente, por ora religiosidades plurais e autocentradas, nas quais cada indivíduo é o único responsável por administrar e estabelecer os parâmetros de sua fé. Daí a definição do sociólogo Flávio Pierucci (2004), para quem em se tratando da América Latina podemos até falar em secularização, mas com intensa mobilização religiosa; ao passo que também a efervescência religiosa passa a ser encarada sob a ótica da secularização.

Pensando o último fenômeno - do crescimento de indivíduos autointitulados "crentes sem religião" e/ou portadores de uma "religiosidade pessoal" - perguntamo-nos: acaso é possível pensarmos em termos de uma religiosidade/espiritualidade não religiosa? Tal movimento denotaria simplesmente o enfraquecimento da dimensão institucional e sua fragmentação nas espiritualidades de caráter privado ou esconderia categorias ainda desconhecidas pelas Ciências da Religião? A fim de respondermos a estas e outras perguntas com as quais nos deparamos, deste ponto em diante nossa inflexão se beneficiará do diálogo com o pensamento de um dos mais significativos autores contemporâneos, quando se cogita de discutir temas como laicidade e o que aqui denominamos por "religiosidades não religiosas". Trata-se do catalão Marià Corbí, habilitado nas áreas de teologia, filosofia e música e, desde as últimas décadas, dedicado à interface dessas searas com o universo científico - vinculação que certamente transparecerá nos excertos mencionados no texto que segue. De nossa parte, utilizaremos duas de suas principais obras atinentes à religião, a saber: Religion sin religion, de 1996, e Hacia una espiritualidad laica, de 2007. ${ }^{3}$ Ao final desse itinerário, pretendemos

2 Para lembrarmos o conceito de Bonhoeffer de um "cristianismo sem religião", que, a seus olhos, configuraria a concreta fé da modernidade: "perante e com Deus, vivemos sem Deus” (BONHOEFFER apud LENAERS, 2014). Aliás, essa temática é recorrente no pensamento de vários autores, entre os quais podemos destacar o texto "Igrejas sem religião, religião sem igrejas?”, de Gianni Vattimo (traduzido e publicado no Brasil).

Apesar de esse segundo livro já se encontrar traduzido para o português, como referência para as citações ao longo do texto privilegiaremos o original em espanhol, traduzindo-o. 
ressaltar quais são, segundo nosso ponto de vista, as principais contribuições desse autor para pensarmos a realidade dos "sem religião" no Brasil, além, naturalmente, de indicar o que julgamos serem alguns dos limites do seu pensamento frente à realidade atual.

\section{Por uma espiritualidade não religiosa?}

Ao tomarmos em conta a Modernidade (conceito com maiúscula), colocamo-nos diante de uma série de acontecimentos em âmbito político, tecnológico e cultural, os quais trouxeram como marca uma profunda ambiguidade. Isso porque, ao mesmo tempo em que podemos tomar esse período histórico (sobretudo os séculos XVII e XVIII) como o pleno acabamento dos ideais de universalização já disseminados desde a alta escolástica (para dizermos da Modernidade como o cumprimento da profecia antevista por pensadores de base platônico-agostiniana), a dicotomização de mundo oportunizada pelo privilegio do modelo racionalista trouxe consigo a invenção da noção de sujeito (campo gnosiológico) e/ou indivíduo (acepção política). Em outras palavras, trata-se do ponto de partida para uma leitura individualizante, autocentrada, para a qual o eu individual passaria a se sobrepor sobre a comunidade: surgiram daí, por exemplo, os primeiros Estados modernos, marcados pela utopia democrática da "igualdade" relacional. Dizemos, então, que ao mesmo tempo em que se estabelece como o cumprimento da expectativa ocidental, o passo individualizante da Modernidade lança as bases para a crise que ulteriormente viria a se desenvolver - como se a própria Modernidade já nascesse marcada pelo pressuposto da crise (e aí está a ambiguidade que a reveste). Seria, portanto, pensando este contexto das grandes revoluções - e, privilegiadamente, da revolução industrial - que Marià Corbí estabeleceria seu marco balizador entre o que denomina como as sociedades "pré-industriais" e, por conseguinte, aquelas posteriores à revolução, em suas palavras, sociedades de "trânsito", ou, o mesmo, "sociedades dinâmicas", 4 por ora marcadas pela fluidez das relações e por uma concepção de identidade igualmente maleável - o que Canclini (2011) nomearia como identidades "performáticas", mais afeitas às regras do teatro e, por isso, da encenação, que às já obsoletas bitolas do conceito, enredadas como sempre estão à estagnação e ao imobilismo.

4 Um paralelo entre as religiões nas sociedades pré-modernas, por um lado, e nas sociedades de inovação contínua, por outro, está disponível em Alberto Moreira e seu artigo introdutório ao pensamento de Marià Corbí (cf. MOREIRA, 2010). 
Nesse interim, segundo Corbí, devemos entender por "religião" a leitura de mundo que se acomodou ao ideário das sociedades "pré-industriais", marcadas por um perfil ordenadamente linear, no qual as respostas - mais que as perguntas - detinham monopólio na imposição de sentido. Para exemplificar o que estamos dizendo, Corbí recorre à metáfora da "taça e do vinho". Quando uma cultura perdura durante milênios exercendo sua hegemonia por meio de práticas programadas e estáticas cujo objetivo é, a todo custo, barrar quaisquer insurgências de mudanças, bem como, alternativas que não lhe digam respeito, corre-se um grave perigo, o perigo de se confundir a taça com o vinho. Em casos como esse a estrutura, o invólucro exterior, torna-se mais importante que o próprio conteúdo o qual tem a responsabilidade de preservar - assim como se deu com as sociedades estáticas ao concentrarem seus esforços na perpetuação de suas instituições, ao contrário de preservarem a vitalidade do conteúdo que detinham. Nessas sociedades, o recipiente (a estrutura institucional) sobrepôs-se ao conteúdo (o vinho festivo da feliz alegoria mencionada pelo autor), uma confusão arriscada ao menos por dois motivos: “[...] por parte da religião: a iniciação religiosa utiliza o prestígio milenário e verificado dos padrões culturais para introduzir-se com mais facilidade e eficácia na coletividade. Por parte da cultura: o programa coletivo se impõe com mais profundidade e força e suas pretensões de exclusividade são mais verossímeis se se revestem de sacralidade" (CORBÍ, 1996, p. 42). Quer dizer que a religião foi a forma encontrada pela cultura para estabelecer o seu domínio. Aliás, um recurso reconhecidamente eficaz, sobretudo em vista das duas últimas capacidades mencionadas pelo autor: torna-se mais verossímil porque se reveste de sacralidade.

Por sua vez, ainda quando se leem os mestres religiosos desde os padrões e paradigmas das sociedades "dinâmicas", pode-se entender como seus ensinamentos parecem sensíveis e fascinantes. Conforme Corbí (1996, p. 43), tal impressão ocorre devido à sua promessa de que o homem está implicado em uma bifurcação existencial, disposto a "duas possibilidades de conhecer, sentir e viver a realidade". A primeira diz respeito à nossa capacidade de viver a partir de nossas necessidades biofisiológicas, ou seja, trata-se de uma esfera a qual o autor nomeia "egocentrada", do indivíduo focado em seu individualismo existencial, na manutenção de suas funcionalidades vitais, algo que beira ao instintivo. A segunda, perfazendo o movimento inverso, avança "para além desta condição de necessidade", num direcionamento que atinge, simultaneamente, a esfera da convivência social (da relação com os demais) 
e da transcendência total, para além de qualquer necessidade. Enquanto a primeira considera o "animal humano", a segunda atinge o âmbito simbólico (de sentidos e significados) do homo religiosus, a perspectiva religiosa ${ }^{5}$ tomada em sentido estrito. Tal pode ser constatado pela capacidade inerente aos mitos e símbolos de modelarem o sagrado e, por meio desse empreendimento, orientarem e dirigirem a mente e a sensibilidade dos indivíduos rumo a experimentarem o que convencionaram como "a outra dimensão" (CORBÍ, 1996, p. 44). Apesar disso, a época atual parece ter chegado ao reconhecimento de uma relatividade que atinge não apenas o âmbito da cultura, mas, por ele, o da religião como um todo - especialmente por se tratar de uma privilegiada forma de expressão da cultura. Os sistemas mítico-simbólicos, dos quais se valia a religião, parecem ter sido questionados pela dinâmica fluida das sociedades industriais: "passamos a outra sociedade mista composta por uma maioria industrial e uma minoria influente, o que poderíamos chamar de uma segunda grande industrialização, à qual vários nomes são dados: sociedade da informação, sociedade do conhecimento, sociedade de inovação" (CORBÍ, 2007, p. 7). Para Corbí (1996), chegamos a essa conclusão por intermédio de duas vias distintas, uma explícita e outra implícita: “[...] a via explícita é o estudo da estrutura das mutações dos sistemas de valores na história. A via implícita é a consciência coletiva, mais ou menos formulada, de que todos os sistemas de valores que convivem em nossa sociedade, todos eles são um sistema e nenhum deles é o sistema" (CORBÍ, 1996, p. 45 - grifos do original). Unindo-se à pretensão de universalidade levada a todo custo até a franja da Modernidade - e, ainda, com significativos impactos sobre esta também a religião se viu em derrocada em face do processo de legitimação da pluralidade de olhares e perspectivas (não necessariamente convergentes entre si). Ao contrário do que houve no passado, o tempo presente não mais está sujeito à imposição de um paradigma como única via possível (como,

Em Hacia una espiritualidad laica o autor apresenta esses mesmos motivos de uma forma diferente: "1. Todas as culturas pré-industriais tiveram religião ou algo equivalente. Somente quando se iniciou a industrialização as religiões começaram a ter sérios problemas com a sociedade. Antes já os havia tido com os intelectuais europeus, mas com a chegada da industrialização esses problemas deixaram de ser somente coisa de intelectuais, apresentando-se também em nível dos grandes coletivos sociais, intelectuais e não intelectuais. [...] 2. Os humanos temos um duplo acesso ao real: um acesso à realidade em função de nossas necessidades, relativo; e outro tipo de acesso ao real independente de nossas necessidades, absoluto. [...] Esta dimensão absoluta de nosso acesso ao real é a que cultivou a religião" (CORBÍ, 2007, p. 12). 
por exemplo, ocorrera por ocasião do contato entre a filosofia grega e seu ideal de Verdade Absoluta e Bem Supremo e a crença judaico-cristã em um "Deus uno", modificada, a partir de então, para a crença em um "único Deus possível") nem para a aquisição do conhecimento, tampouco para o relacionamento com o transcendente.

Por conseguinte, as análises de Corbí denunciam que o que até agora se entendeu por "religião" (evocando o aspecto mais propriamente institucional que relativo à capacidade de crer) chegou ao fim. Entre outros motivos, isso ocorreu graças a um indicativo que para nós parece muito importante: embora a religião tenha sempre se apresentado como um sistema coletivo de crenças, é bem verdade que na medida em que se consolidou como "sistema" também adquiriu a conotação do "controle social". Nas palavras de Corbí (1996, p. 46), "um sistema coletivo de crenças é, também, um sistema de controle coletivo. Todo sistema de controle requer um sistema de poder". Dito de outro modo, o pensador catalão tenta demonstrar que a mesma capacidade inerente à linguagem mítico-simbólica como veículo de propagação da religião foi utilizada como "veículo de programação coletiva das maneiras de pensar, sentir e atuar, as quais devem ser fixadas de forma intocável e rigorosamente controlada. As religiões estão, por isso, conectadas com as crenças, o controle e o poder" (CORBÍ, 1996, p. 46). O problema é que as transformações culturais das sociedades industriais (e, por isso, dinâmicas) puseram fim a essa situação. Estaríamos, a esta altura, submetidos a uma realidade do pós-religioso - da secularização ou da crise de plausibilidade, para novamente recobrarmos os conceitos de Berger (1988) - ou, na melhor das hipóteses (e o que, de fato, defendemos) numa fase de transição, isto é, numa "crise epocal" do conceito de religião: que, voltando à sua acepção mais originária (crença e/ou religiosidade), deve desvestir-se do caráter institucional adquirido ao longo dos séculos passados. O presente impõe-se, então, como cenário de muita religiosidade, embora de pouca religião - sendo esta tomada no sentido da instituição e tudo o que lhe diga respeito (dogmas, ritos, teologia). Sobre isso salienta o autor:

$\mathrm{Na}$ nova situação de mudanças aceleradas em todas as ordens, o colapso dos sistemas axiológicos herdados, a convivência de toda a diversidade de culturas, as grandes transformações sofridas em curto espaço de tempo, a dinâmica das novas sociedades que vivem e prosperam criando continuamente novas ciências e novas tecnologias, novos produtos e novos serviços, nos fizeram compreender que todas as nossas maneiras de pensar, sentir, organizar e viver são construções nossas; que nada nos vem dos céus, nem, tampouco, da natureza mesma das coisas (CORBÍ, 2007, p. 9-10). 
Até pouco tempo, chamávamos "religião" o modo peculiar de viver a experiência sagrada, próprio das sociedades pré-industriais - aquelas que, segundo Corbí, viveram durante séculos reproduzindo o mesmo modelo de produção. Como mecanismo de autopreservação, tais sociedades se opuseram a tudo o que representava o diverso, bloqueando e deslegitimando a mudança e a transformação, mantendo imóveis seus sistemas de programação social. ${ }^{6}$ Daí que, para Corbí, as "religiões" sejam "as formas sagradas pré-industriais que se expressam em programas mítico/simbólicos, que são programas culturais de domínio, controle, submissão e exclusão de alternativas" (CORBÍ, 1996, p. 46 - grifos do original). Ao passo que a dimensão mística - dimensão da espiritualidade e, quiçá, da religiosidade - melhor poderia definir o relacionamento com o totalmente Outro. Diante disso, três principais motivos são apresentados pelo autor a fim de justificar o enfraquecimento do sistema religioso nas sociedades dinâmicas e sua substituição por novas possibilidades místicas. Em primeiro lugar, "abandonam-se os sistemas miticos/simbólicos de programação substituindo-os por procedimentos cientificos e ideológicos" (CORBÍ, 1996, p. 47-48 - grifos do original). A ciência passa a ocupar não apenas o lugar da filosofia, mas também o da religião junto às sociedades. Aqui podemos destacar o elemento positivista presente no argumento de Corbí, segundo o qual a ciência representaria a última resposta da humanidade diante dos desafios da vida cotidiana, repleta por desventuras, fracassos, catástrofes, doenças etc... Em outras palavras, a ciência ocuparia o espaço que antes era dominado pelas narrativas sagradas - permanecem, então, os mitos e simbolismos, embora agora traduzidos por mitos e símbolos do universo científico (e isso para darmos apenas uma pequena agulhada no argumento de Corbî). Em segundo lugar, "abandonam-se os sistemas estáticos de programação coletiva" (CORBÍ, 1996, p. 48). Trata-se de recobrar o caráter performativo das sociedades industriais, marcadas por um processo dinâmico e constantemente retroalimentado pela propulsão da produção e do consumo. Estas são, por isso, sociedades programadas para o movimento contínuo (aliás, seguindo a mesma lógica do capitalismo). Criam e recriam ci-

6 Em outro lugar o autor também se refere a este tema: "a religião é, então, a forma de viver a experiência da dimensão absoluta da realidade sob o domínio e o controle dos programas coletivos das sociedades pré-industriais, que são todas estáticas. As sociedades dinâmicas, que carecem de sistema de fixação e exclusão, deverão distanciar-se desta noção e aprender a distinguir, com toda claridade, o vinho da taça. A iniciação à experiência da dimensão absoluta de viver terá que se emancipar dos sistemas fixos de crenças, valores e comportamentos, e assim mesmo, deverá dirigir-se a contextos fluidos de inovação e livre indagação" (CORBÍ, 2007, p. 149). 
ência e tecnologia de modo a responder ao apelo do mercado. Distanciam-se das "velhas religiões", pautadas por programas estruturados que visavam fixar e bloquear a mudança. Finalmente, em terceiro lugar, "abandonam-se os sistemas exclusivistas de programação porque tem que se coordenar a globalidade e a pluralidade própria de uma sociedade universal e criativa" (CORBÍ, 1996, p. 48). Dada a liberdade criativa instaurada pela nova ciência, também a religião poderá se expressar de maneira plural, com ênfase na liberdade de escolha por parte dos indivíduos. Como reflexo no presente, testemunhamos o advento de iniciativas religiosas particulares, espiritualidades ou comportamentos espiritualizados livres de qualquer ordenamento institucional. ${ }^{7}$ Isso significa, segundo Corbí, que:

[...] está nascendo uma nova maneira de viver e expressar as experiências religiosas. A essa nova maneira de viver as experiências religiosas já não devemos chamar religião porque o termo sugere fixação, domínio, submissão, controle do pensamento, do sentir, da moralidade, dos modos de vida, das crenças e rituais; diz-se exclusivismo e exclusão; diz-se organização hierárquica de controle ideológico em mãos de um grupo e uma casta (CORBÍ, 1996, p. 48).

Desse modo, também por parte das Ciências da Religião ou da Teologia surge a necessidade de se propor e discutir novas categorias que melhor correspondam ao atual estado das coisas - quem sabe o que atualmente se tem discutido acerca dos denominados "crentes sem religião", cada vez mais expressivos conforme demonstram tanto as pesquisas realizadas por ocasião do senso do IBGE de 2010, quanto do que pudemos aferir em duas pesquisas junto aos jovens universitários da PUC Goiás. ${ }^{8}$ Apesar disso,

\footnotetext{
Ressalta Corbí (2007, p. 151): “essa nova maneira de se viver a espiritualidade já não deveríamos chamar religião, porque o termo sugere fixação, domínio, submissão, controle do pensamento e do sentir, controle da moralidade, dos modos de vida e das crenças. "Religião" evoca ideias de exclusivismo e exclusão, organização hierárquica de controle ideológico nas mãos de um grupo. A dimensão espiritual não é uma explicação dos mistérios da existência, nem uma explicação da vida e da morte, nem uma solução aos problemas metafísicos da existência. Não soluciona nada, apenas cria pessoas capazes de criar explicações e resolver problemas. A espiritualidade não é um sistema de crenças; não pode, pois, controlar nada. E não apenas não controla nada, mas faz cair em pedaços qualquer sistema de controle, porque põe em contato com a realidade de uma maneira tal que relativiza qualquer forma de pensar, sentir e viver".

8 Ver resultados do CENSO IBGE 2010 (cf. TEIXEIRA; MENEZES, 2013), bem como as pesquisas "Culturas e ateísmos contemporâneos" e "Juventude e religiosidade: o caso de jovens universitários da PUC Goiás", ambas realizadas junto aos estudantes da Pontifícia Universidade Católica de Goiás, com autorização do Comitê de Ética em Pesquisa, sob os números CAAE, respectivamente: 48968115.4.0000.0037 e 38480614.1.0000.0037 (em vias de publicação).
} 
isto é, da insuficiência do termo "religião" para designar o comportamento religioso dos indivíduos oriundos das sociedades dinâmicas, devemos concordar com o próprio Corbí quando reconhece que também não é possível evitar totalmente o seu uso, particularmente porque ainda carecemos de um substituto coletivamente aceito para tal. Daí a advertência referente a toda a argumentação desenvolvida tanto em Religion sin religion (1996), quanto em Hacia una espiritualidade laica (2007): "usarei o termo, mas o farei referindo-me a outra coisa que o que tradicionalmente se entendida, porque aquilo a que o termo se referia, o que se entendia por religião, se acabou" (CORBÍ, 1996, p. 48). Em vista do que acabamos de dizer, cabe, então, impor os seguintes questionamentos: o que não podemos esperar das religiões segundo a ótica do autor? O que, em outras palavras, a religião não é?

Tomando o horizonte de Religion sin religion, seis principais categorias podem ser apontadas a fim de justificar o que a religião não é - ou, ao menos, o que deixou de ser para as sociedades industrializadas, como segue: 1) a religião não é uma explicação da realidade, não é uma explicação dos mistérios da existência, como a vida e a morte, nem, sequer, uma solução aos problemas metafísicos e existenciais - note-se, outra vez aqui, a influência positivista de uma crença ilimitada na ciência como única fonte de respostas para o homem; 2) a religião não explica nada, nem resolve nada, porque introduz um modo de conhecer e sentir a realidade que é silencioso, ou seja, introduz a um tipo de conhecimento que não é da mesma ordem da explicação racional - a religião, por ela mesma, não explica nem desvenda nada, apenas cria homens com condição para tal; 3) a religião não pode dar certezas - porque esta é uma dimensão propriamente científica - a respeito de verdades, preceitos e valores; ${ }^{4}$ 4) a religião não pode ditar o comportamento das pessoas, como devem viver; não pode, por isso, meter-se com os problemas mais radicais da existência; 5) a experiência religiosa é vazia de soluções porque não é nem interpretação, nem representação, nem articulação de nenhum tipo - é, ao contrário, uma presença densa e silenciosa, uma presença que abarca o ser humano em todas as suas dimensões, encorajando-o à ação; 6) a religião, enfim, não pode oferecer uma verdade nos termos de uma verdade lógica, porque a verdade oferecida pela religião é "uma verdade que é desnuda e completa, e uma valoração da realidade que libera de toda forma e de toda submissão" (CORBÍ, 1996, p. 51 - grifos do original).

\footnotetext{
$9 \quad$ Note-se a ênfase positivista.
} 
Em contrapartida, é inegável que esses indicativos do que a religião não mais pode ser para a sociedade atual por si sós já representem uma conceituação negativa, ou seja, evocando o que, então, a religião deve ser. Isso porque, para Corbí, o convite das tradições religiosas não é meramente alusivo a um programa ou projeto de vida, nem, tampouco, a uma filosofia moral. $\mathrm{Na}$ verdade, "o que se propõe é assumir o próprio destino, indagando-o e criando-o até realizar com esta criação a realidade de nossa condição e chegar, assim, ao outro lado da fronteira que aqui mesmo se apresenta. A religião é uma indagação" (CORBÍ, 1996, p. 54 - grifos do original). Trata-se da exposição de uma espécie de religião existencial - já presente na concepção tradicional de religião, embora mais fortemente reforçada pela contemporaneidade. Os mestres religiosos seriam, por isso, mestres da indagação - como o fizeram os filósofos do passado. Não seriam os responsáveis por ditar o caminho a ser seguido, por se tratar de um direcionamento que apenas se cria a cada novo passo dado, sem maiores pretensões de onde chegar. Entendida dessa maneira, segundo Corbí a religião seria uma proposta estendida a todos os humanos - um dado classificatório de sua humanidade, como reconheceu o filósofo Feuerbach $(1988)^{10}$ na abertura de sua crítica antirreligiosa. Nesse sentido, é o próprio Corbí quem afirma: "a Religião é a maior das possibilidades humanas, não é necessário ‘temperá-la' para que possa agradar a todo paladar" (CORBÍ, 1996, p. 54). Não mais, porém, o modelo de religião utilizado como estratégia de controle social, de domínio cultural e moral, mas a religião (religiosidade) assumida como o passo mais radical rumo à liberdade individual e de consciência, uma aposta na dimensão mais profundamente humana: a capacidade de escolher o próprio caminho, de autoguiar-se, de construir-se a si mesmo. Diz Corbí (1996, p. 58): "se a Religião deixa de ser submissão, deixa de ser, igualmente, exclusivista e excludente. A Religião como liberdade completa e criação livre, deixa de ser excludente e se faz acolhedora". Dito de outro modo, "religião" deixa de ser sinônimo de exclusividade e homogeneidade, adquirindo contornos plurais e de iniciativa individual (sem a pretensão de que um ou outro credo se levante como a verdade em termos de sacralidade).

Há, portanto, uma verdadeira guinada, de modo que a oferta religiosa passa a ser compreendida - novamente com o recurso da metáfora - como uma viagem que não tem fim nesta terra, neste ou naquele lugar. Caso alguém

10 Tivemos a oportunidade de desenvolver esse assunto em "Religião e Ateísmo em Ludwig Feuerbach", uma publicação de 2017, e "Ateísmo e Religião em Ludwig Feuerbach: uma aposta na essencialidade do humano", publicado em 2016 - vide referências. 
aceite tomar parte nesta viagem, se porá em movimento pelo caminho do conhecimento, da comoção e da liberdade. Para Corbí, os indivíduos religiosos da sociedade pré-industrial achavam-se divididos, criam e agiam involuntariamente desde suas crenças. Por meio delas, contudo, não se permitiam sentir-se em "carne e osso", embrenhar-se num processo de refinamento de seus sentidos e sentimentos: "homens de conhecimentos religiosos frios, carentes de calor, carentes de espontaneidade e ternura" (CORBÍ, 1996, p. 58). Pautada pelo paradigma moderno, também a religião reproduzia um ser humano cindido, em que a dimensão do conhecimento (razão) se sobrepunha à do sentir. Este, em outras palavras, foi o passo decisivo não apenas para a crise da racionalidade que se abateu sobre o Ocidente, mas também para a crise de plausibilidade das religiões que se assentaram sobre tal estrutura (note-se o insurgente apelo sentimentalista das práticas religiosas que se multiplicaram - saindo de um extremo e caindo no outro e, por isso, mantendo o mesmo modelo dominador, antes pela razão e agora pela emoção). Assim, na perspectiva de Corbí, não há outro modo de se falar em religião na atualidade senão inserindo-a no horizonte das novas condições culturais:

[...] só é legitimo falar de religião caso faça-se com plena liberdade e responsabilidade, sem submissões de nenbum tipo. Toda espécie de submissão desvaloriza e desacredita definitivamente o que se refere a questões religiosas, como a submissão desacredita o que se possa dizer em ciência ou em arte. Somente a qualidade é o critério; a qualidade e a responsabilidade. Quando a qualidade e a responsabilidade se convertem em critério, a submissão, o controle e a vigilância extrema ficam deslegitimadas (CORBÍ, 1996, p. 61 - grifos do original).

Estes dois critérios - qualidade e responsabilidade - marcam o que Corbí entende como a autêntica prática religiosa das sociedades industriais (ou dinâmicas). Isso porque a qualidade da experiência vivenciada, que supõe a imersão do indivíduo em sua totalidade, bem como a responsabilidade do que se pratica com relação aos demais, deixam de lado o antigo critério do controle social: a religião é legítima quando serve ao indivíduo e não quando o torna objeto do domínio de outrem. Assim, dá-se maior ênfase ao caráter insurgente da religião que, propriamente, à sua capacidade de manutenção da ordem estabelecida. A religião, diz Corbí (1996, p. 62), "envia-nos a recuperar e viver intensamente nossa liberdade constitutiva”, nos impulsiona ao âmbito do que está além do domínio de nossas necessidades, torna-se opção e não mera obrigação: "posto que a religião nos convida a caminhar pelos campos da realidade que não modela nossa necessidade, nos convida à liberdade de toda submissão, porque só a 
necessidade submete. A religião é, por isso, um convite à liberdade sem limites" (CORBÍ, 1996 , p. 62 - grifos do original). Apenas nesse caminho de pura liberdade para crer se descobrirá a autêntica dimensão do ser humano como alteridade, como solicitude às necessidades dos que estão ao seu redor. $\mathrm{Na}$ medida em que abdica de todo interesse por domínio a religião pode dedicar-se à vida concreta dos que a cercam e dela tomam parte, plantando entre os homens o esperado Reino de Deus, que nada mais é senão o reconhecimento da solidariedade e da ternura em tudo e em todos. Isto posto, também as formas tidas como convencionais de se praticar a religião (e aqui no sentido de religiosidade ou crença) sedem lugar aos novos modos, adaptados à dinâmica da sociedade contemporânea. A essas novas formas de se viver a religião Corbí nomeará "práticas pós-convencionais": "saímos da época das sacralidades. Até os que se confessam crentes estão entrando nessa situação. Isso não quer dizer que não haja ordens consideradas mais perduráveis que outras" (CORBÍ, 2007, p. 157).

Enfim, se, como dissemos, as sociedades pré-industriais tiveram que conviver com a estagnação e, por isso, adotar instrumentos que legitimassem e tornassem hegemônica tal cosmovisão, nenhum "remédio" poderia lhes fazer mais sentido do que viver também a religião de forma estática e convencional. A religião homogênea era, portanto, a forma de se compreender o fundamento indiscutível da moral e do sentido da vida cotidiana. Não havia qualquer possibilidade que fugisse a esse modelo - com exceção de algumas iniciativas de caráter popular, abundantes desde a Idade Média. A única possibilidade recaía sobre a esfera individual, num movimento contra a corrente. Daí que de acordo como foram legadas, as religiões (instituições regulamentadas) chegaram ao presente como "formas convencionais de ler os mestres desde a perspectiva cultural das sociedades estáticas; [...] formas homogêneas, uniformes, fixadas, convencionais e impositivas de viver os ensinamentos dos mestres" (CORBÍ, 1996, p. 68 - grifos do original). Dessa forma, não seria espantoso que o advento da consciência individual e, mais que isso, sua sobreposição sobre a dinâmica social, unido à decorrente valoração da liberdade de escolha, estabelecessem diante de tal modelo uma forte repulsa. Por conseguinte, se em relação aos indivíduos das sociedades pré-industriais notamos uma considerável mudança em comparação com os homens e mulheres ${ }^{11}$ dos dias atuais, igual evolução no modo de portar-se e se reconhecer não pode ser extraída das religiões (sobretudo considerando as grandes religiões do Ocidente, com especial ênfase para o

11 Cf. Corbí (2007, p. 159-160): "os homens e mulheres das novas sociedades devem rechaçar a crença em todos seus âmbitos, também e especialmente nos âmbitos da moralidade e da religião; e tem que fazê-lo porque, para integrar-se à nova sociedade, devem abandonar os padrões que construíram os sistemas de vida e programação das sociedades estáticas". 
cristianismo - seja ele de viés católico ou protestante). Tal disparidade resulta na incapacidade de os indivíduos da sociedade dinâmica se enxergarem nos parâmetros oferecidos por essas religiões, cujo resultado pode ser a completa recusa da dimensão religiosa (se é que isto seja realmente possível), expressa nas mais diversas formas de ateísmos ou agnosticismos, ou, o que parece ter feito mais sentido - ao menos para os latino-americanos - a implantação de religiosidades não institucionalizadas ou, melhor dizendo, avessas a quaisquer tentativas de submissão a este ou àquele credo denominacional.

Trazendo para o curso do que já dissemos e, ao mesmo tempo, amparados pela ótica de Marià Corbí, o grupo dos denominados "sem religião" (que também inclui os que preferem subscrever-se na esfera de uma "religiosidade pessoal" ou "outras formas religiosas") seria o resultado do confronto entre uma sociedade que não se manteve isenta aos resultados apresentados pela crise deflagrada desde a modernidade versus instituições que perfizeram um caminho à revelia desse influxo - numa escala de posicionamentos que vão desde simplesmente ignorá-lo, passando pela tentativa de estabelecer diálogo com a atualidade, até a absoluta repulsa, cujo resultado é o aberto confronto. ${ }^{12}$ Embora não se trate de um processo de fácil empreendimento, concordamos com Corbí quando afirma não haver outra forma de superar esse dilema senão abandonar as velhas maneiras de se fazer o caminho religioso: "não podemos fazer o caminho religioso como o fizeram nossos antepassados. Tem-se que abandonar, com claridade e decisão, as velhas formas agrárias, autoritárias, patriarcais e exclusivistas de fazer o caminho religioso" (CORBÍ, 1996, p. 78). De volta à metáfora do vinho e da taça é preciso optar pelo conteúdo, isto é, pelo vinho, em detrimento de seu receptáculo. O conteúdo sagrado da religião, como impulso ao homem rumo à sua completa liberdade, obriga-nos à proposição de novas formas de absorvê-lo (novas vivências religiosas?):

Se quisermos beber o vinho, não temos mais remédio que usar outras taças. Temos que lavrar novas taças com nossos melhores materiais e com o maior dos cuidados. É doloroso ter que abandonar as velhas e veneráveis taças e é

12 No catolicismo, por exemplo, é possível identificar estes três momentos distintos. O posicionamento do magistério católico das últimas décadas demonstra posições que vão desde simplesmente ignorar a modernidade, como se a Igreja estivesse isenta à sua influência, passando por posições mais moderadas, abertas ao diálogo e ao mútuo enriquecimento, chegando à plena oposição, amparada por discursos contra suas consequências no âmbito da cultura e da fé (o relativismo), das relações entre os homens (o hedonismo) e das relações sociais (o consumismo). 
arriscado ter que construir taças novas dignas de receber o vinho sagrado; mas não temos outra solução; essa é a lei inviolável do seguimento das tradições; essa é a autêntica fidelidade, a única possível nas novas circunstâncias (CORBÍ, 1996, p. 78 - grifos do original).

É verdade que, em última instância, o autor nos conduz a um completo abandono da religião, ao menos tal como esta fora (é?) concebida, substituindo-a por um modo possível de exercer a laicidade. No entanto, não podemos entender por laicidade - ao menos no prisma destas reflexões - o simples esvaziamento do lugar de Deus nas sociedades hodiernas. De fato, as sociedades científicas, tecnológicas e industriais, em meio aos seus avançados processos de produção e consumo, não pressupõem em suas tramas culturais um espaço para Deus - este ente conceituado por filósofos, teólogos, sociólogos e outros autores do passado (e refletir sobre isso nos levaria a outro artigo, quem sabe mais centrado nestas abordagens teóricas). Tais sociedades não mais se valem da religião para interpretar seus diferentes níveis sociais, ou os sistemas de valores que professam, tampouco para fundamentar a ética em que baseiam seus comportamentos (individuais e coletivos). Por detrás dessa aparente impossibilidade, contudo, guardam espaço para o oferecimento do caminho interior - segundo Corbí, como um processo rumo ao silêncio ${ }^{13}$ - próprio da autêntica experiência religiosa. Estaríamos, então, falando de novas formas de espiritualidade (ou religiosidades) não religiosas? Seria este o caso dos "crentes sem religião"?

\section{Considerações finais e últimas provocações: Corbí e os "sem religião"}

À guisa de conclusão, tentaremos resumir quais são, a nosso ver, as principais contribuições oferecidas por Corbí a fim de pensarmos a realidade dos "sem religião" no Brasil - e na América Latina como um todo. Em primeiro lugar, é preciso reconhecer que a proposta oferecida por esse autor visa, como ponto nevrálgico de sua argumentação, a superação da religião. Corbí mesmo reconhece, como já vimos, que a insistência no uso do termo "religião" apenas ocorre por falta de um novo conceito que lhe substitua. Ainda

13 Essa nova forma de se viver a "espiritualidade", que, para Corbí, está intimamente relacionada ao exercício da liberdade e do silêncio interior, é considerada em seu livro Silencio desde la mente, cuja proposta corrobora - por ora num horizonte prático - a noção de uma "espiritualidade laica", conforme defendido em outras de suas obras. 
que a sociologia e a antropologia insistam em perscrutar as novas realidades que se insurgem em busca de compreendê-las, a dificuldade na elaboração de conceitos "à ordem do dia" também esbarra na mutabilidade dos fenômenos. Mais que uma mudança de época, estamos na época da permanência das mudanças! A lógica conceitual parece, então, enfraquecida, mostrando-se sempre a quem dos processos histórico-culturais. Nesse sentido, o mesmo poderíamos dizer com relação a termos como "religiosidade" e/ou "espiritualidade", os quais utilizamos neste trabalho marcando distância de uma compreensão institucionalizada da crença que, em se tratando dos atuais "sem religião" se veria justificada. A laicidade defendida por Corbí tem em vista negar que a religião alcance qualquer herança possível, demonstrando que as estruturas típicas do pensamento religioso tornaram-se obsoletas para as sociedades dinâmicas das eras "industrial" e "pós-industrial". Assim, apenas o silêncio e o cultivo de um exercício espiritualizado (e também este termo apresenta seus limites) se tornariam a resposta contemporânea aos anseios existenciais e morais que ultrapassam a dimensão biofisiológica dos indivíduos - respostas que antes eram oferecidas (unicamente) pela religião. Curiosamente, apesar de seu aparente ineditismo, caso tomemos um contexto mais abrangente, a previsão antevista por Corbí, combinada com sua respectiva solução para a manutenção de sentido (sentido este que os indivíduos não mais buscariam nas práticas religiosas), pode ser contraposta por, pelo menos, dois modelos que se mostram mais evidentes: o advento de cientificismos/positivismos no século XIX e o exemplo das tradições não ocidentais.

Começando pelo segundo ponto, devemos reconhecer que, a fim de justificar suas análises, Corbí toma como paradigma a sociedade Ocidental, inclusive forçando-a como modelo de análise para todo o restante do globo. Fato é que o Oriente não se prestou aos mesmos itinerários percorridos pelas sociedades ocidentais: por um lado, devido à anterioridade de suas cosmovisões, significativamente mais antigas que a tradição judaico-cristã, hegemônica no Ocidente; em segundo lugar, por não ter se prestado ao mesmo modelo dicotômico e/ou dualista ainda vigente no Ocidente desde a Modernidade. Daí que algumas de suas práticas de vivência da religião (note-se o Budismo e o Confucionismo, por exemplo) expressem-se a despeito da necessidade de se definir o "ser divino", nos moldes de uma filosofia de vida, o seguimento de uma filosofia ou sabedoria familiar. Isso para não falarmos de outras culturas e tradições, tais como aquelas baseadas na oralidade (como alguns povos africanos), ou a influência de leituras de mundo que se prestam 
a aproximar o conhecimento religioso e a efetividade da vida prática, assim como ocorre na absorção dos saberes indígenas de modo especial pelas comunidades rurais (mas não somente!). Isto posto, devemos reconhecer a insuficiência de se tomar o paradigma ocidental, com sua égide marcadamente europeia, em prol de se compreender o "futuro da religião" no planeta. Em terceiro lugar, em vários momentos os argumentos de Corbí exalam odor semelhante ao do positivismo no século XIX (que, curiosamente, impactou o Brasil mais que a qualquer país). Nesse sentido, os últimos desdobramentos do positivismo podem nos servir de alerta frente a discursos que queiram banir a religião da vida em sociedade, particularmente porque tais iniciativas mostraram-se incapazes de preencher o espaço simbólico antes ocupado pela crença religiosa. O próprio positivismo viu-se obrigado a converter-se em religião - um contrassenso no mínimo provocante, como forte advertência para leituras fatalistas da religião.

Segundo nos parece, Corbí estaria correto ao afirmar a superação da religião por novos campos de "capital simbólico" - para recordarmos a expressão de Pierre Bourdieu (1998). Entretanto, não no sentido de que a laicidade se afirmaria como a total abolição da religião do espaço público, mas como o próprio Corbí de algum modo parece apontar, pela superação da religião pela própria religião. Embora não haja o uso de um novo termo em substituição ao antigo - pelos motivos já mencionados - o que Corbí denomina por religião nas sociedades industriais em nada deve assemelhar-se ao antigo uso desse termo. Isso porque não mais se trata de religião tida como estratégia de domínio e/ou controle social, mas como efetiva possibilidade de libertação, não apenas "deste vale de lágrimas" e sofrimentos, em vista de uma vida futura, mas como o reconhecimento por parte de cada indivíduo de suas potencialidades internas, as quais devem motivá-lo ao relacionamento com os outros e com a natureza toda. Por isso falarmos em espiritualidades (ou religiosidades) não religiosas, já que para nós um ponto viável para aproximarmos a leitura oferecida por Corbí e o crescente fenômeno dos "sem religião" é o reconhecimento da religião em seu aspecto institucional. Desse modo, a herança de uma compreensão de religião como instituição, legada pelas sociedades pré-industriais - isto é, estáticas e monopolizadoras - estaria na raiz do comportamento praticado por uma significativa parcela da população brasileira e latino-americana nos dias atuais. Ao que parece, em se tratando desse contexto mais específico, os influxos da globalização, acompanhados pela secularização, a crise de plausibilidade e o desencantamento 
alcançaram com mais força o âmbito das instituições que, propriamente, a esfera dos indivíduos. Portanto, resta ao presente uma representativa gama de indivíduos altamente afetados pela religiosidade, embora se neguem inseridos neste ou naquele credo confessional.

Enfim, seria ingenuidade de nossa parte não levantarmos um último ponto: apesar de, como dissemos, o enfraquecimento das instituições religiosas e a propagação de crentes sem religião coadunar-se, nalguma medida, com a leitura de Corbí, de que religiosidade - em sentido estrito - estaríamos realmente falando? Trata-se, então, da instituição da laicidade como resposta à crescente crise institucional, o que reforçaria o argumento do pluralismo religioso e o crescimento das chamadas "espiritualidades laicas"? Respondendo a estas demandas, nossa reflexão se depara com novos desafios. Se, por um lado, o aspecto da pluralidade parece ganhar maior destaque, por outro, caso aproximemos nosso foco, se tornará possível diagnosticar que por detrás da aparente independência com relação às instituições, também o universo dos "crentes sem religião" se apresenta profundamente marcado por princípios, em sua maioria, colhidos da seara cristã. Assim sendo, seria mesmo legítimo aplicarmos a expressão "crentes sem religião" ou, na melhor das hipóteses, deveríamos considerá-los como "cristãos desigrejados"? ${ }^{14}$ Isso para não falarmos da dimensão axiológica, já que na raiz da civilização ocidental está a influência crucial do judaico-cristianismo, sua visão de mundo, seu conjunto de valores e crenças. $\mathrm{O}$ aparente pluralismo poderia, por isso, ser apenas o escamoteamento da manutenção de uma mesma ordem, ou seja, a maneira de a atualidade exercer a sua hegemonia (diferente do passado), assegurada pelo consenso na concepção de bem, no ordenamento dos valores sociais e na moral a ser praticada. Frente a esta situação, para nós as intuições de Corbí devem ser melhor definidas como pontos de partida, isto é, estímulos e provocações, que, propriamente, como respostas.

14 E isso concordaria com o que Alonso Gonçalves desenvolve em "Uma espiritualidade sem Igreja”, 2013. Ou com o que Sandra Duarte de Souza sentencia: "as instituições tradicionais produtoras de sentido têm se deparado com a precariedade do engajamento das pessoas com o seu sistema de crenças [...]. [Assim,] o sujeito de fé tem feito suas próprias combinatórias simbólicas, transitando em diversas expressões religiosas e apropriando-se de significantes específicos de acordo com a especificidade de suas necessidades" (SOUZA, 2001, p. 159). 


\section{Marià Corbi e os sem religião}

\section{Referências}

BARRETO, Tobias. A Cultura Acadêmica. Recife, ano I, vol. I, jul./ago. 1904 (Tomo I, fasc. I), p. 3-18.

BASTIAN, Jean-Pierre. La Mutación Religiosa de América Latina: para una sociología del cambio social en la modernidad periférica. México: Fondo de Cultura Económica, 1997 (Colección Popular n. 529).

BERGER, Peter Ludwig. O dossel sagrado: elementos para uma teoria sociológica da religião. Tradução de José Carlos Barcellos. São Paulo: Paulinas, 1985 (Coleção sociologia e religião; 2).

BOURDIEU, Pierre. A economia das trocas simbólicas. Tradução de Sérgio Miceli, Silvia de Almeida Prado, Sonia Miceli e Wilson Campos Vieira. São Paulo: Editora Perspectiva, 1998.

CANCLINI, Nestor García. Culturas híbridas: estratégias para entrar e sair da modernidade. Tradução de Heloísa Pezza Cintrão, Ana Regina Lessa; tradução da introdução de Gênese Andrade, 4. ed., 5ª reimp. São Paulo: Editora da Universidade de São Paulo, 2011 (Ensaios Latino-americanos, 1).

CORBÍ, Marià. Hacia una espiritualidad laica: sin creencias, sin religiones, sin dioses. Barcelona: Herder Editorial; Grammata.es, 2007.

CORBÍ, Marià. Para uma espiritualidade leiga: sem crenças, sem religiões, sem deuses. São Paulo: Paulus, 2010.

CORBÍ, Marià. Religión sin religión. Madrid: PPC; Servicios Koinonia, 1996.

CORBÍ, Marià. Silencio desde la mente: prácticas de meditación. Barcelona: Bubok, 2011.

ECCO, C.; MARTINS FILHO, J. R. F. “Ateísmo e Religião em Ludwig Feuerbach: uma aposta na essencialidade do humano". In: Caminhos, v. 14, n. 2, jul./dez. Goiânia, 2016, p. 325342. ECCO, C.; MARTINS FILHO, J. R. F. "Religião e Ateísmo em Ludwig Feuerbach". In: COSTA, C. L. F.; ECCO, C.; MARTINS FILHO, J. R. F. Epistemologias da religião e relações de religiosidade. Curitiba: Editora Prismas, 2017.

FEUERBACH, Ludwig. A essência do cristianismo. Tradução de José da Silva Brandão. Campinas, SP: Papirus, 1988.

GONÇALVES, Alonso. "Uma espiritualidade sem Igreja: a emancipação institucional e o surgimento de novas experiências religiosas”. In: Ciberteologia - Revista de teologia e cultura, ano X, n. 45, 2013, p. 4-18.

LENAERS, Roger. Viver em Deus sem Deus? Tradução Carlo Tursi, 1. ed. São Paulo: Paulus, 2014.

MARTUCCELLI, Danilo. "Para abrir la reflexión - etnicidade modernas: identidades y democracia”. In: GUTIÉRREZ MARTÍNEZ, Daniel (Coord.). Multiculturalismo: perspectivas y desafíos. México: Siglo XXI, 2006 (Sociologia y política).

MOREIRA, Alberto da Silva. "Religiosidade laica: uma introdução ao pensamento de Marià Corbî”. In: Horizonte, v. 8, n. 19, out./dez. Belo Horizonte, 2010, p. 21-40. 
PIERUCCI, Antônio Flávio. "Secularização e declínio do catolicismo". In: SOUZA, Beatriz Muniz de; Martino, Luís Mauro Sá (Orgs.). Sociologia da religião e mudança social: católicos, protestantes e novos movimentos religiosos no Brasil. São Paulo: Paulinas, 2004.

PIERUCCI, A. F. O Desencantamento do mundo: todos os passos do conceito em Max Weber. São Paulo: Editora 34, 2003.

SOUZA, Sandra Duarte de. "Transito religioso e construções simbólicas temporárias: uma bricolagem contínua". In: Estudos de religião, São Bernardo do Campo: UMESP, ano 15, n. 20, jun., 2001.

TEIXEIRA, Faustino; MENEZES, Renata (Orgs.). Religiões em movimento: o censo de 2010. Petrópolis, Vozes, 2013.

VATTIMO, Gianni. "Igrejas sem religião, religião sem igrejas?”. In: Interações - Cultura e Comunidade, Uberlândia, v. 5, n. 7, jan./jun. 2010, p. 165-172.

WEBER, Max. A ética protestante e o “espírito” do capitalismo. São Paulo: Companhia das Letras, 2004.

Submetido em: 19-5-2017

Aceito em: 12-8-2018 